\title{
EFFECTIVENESS OF RESINS/EXUDATES OF TREES IN CORROSION PREVENTION OF REINFORCEMENT IN REINFORCED CONCRETE STRUCTURES
}

\author{
A. W. Otunyo ${ }^{1, *}$ and C. Kennedy ${ }^{2}$

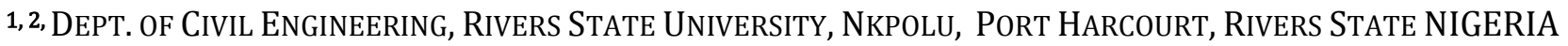 \\ E-mail addresses: ${ }^{1}$ umutuigili@yahoo.com, ${ }^{2}$ ken_charl@yahoo.co.uk
}

\begin{abstract}
Corrosion of steel reinforcement is one of the important factors that are responsible for the short service life of reinforced concrete members, in marine structures like bridges, piers and jetties. This study, investigated the effectiveness of resin/exudates in corrosion prevention of reinforcement in reinforced concrete cubes. The reinforced concrete cubes of dimension $(150 \mathrm{~mm} \times 150 \mathrm{~mm} \times 150 \mathrm{~mm}$ ) were coated with dacryodes edulis resin paste of various thicknesses: 150um, 250um, and 300um. The reinforced concrete cubes were exposed to a corrosive environment for 60days after 28 days of curing. in order to stimulate accelerated corrosion of the reinforcing steel. Another test was carried out with steel reinforcement cubes, whose steel reinforcement were not coated with dacryodes edulis resin but also exposed to the same corrosive environment. for the same 60 days after 28 days curing. The control test was carried out with a set of concrete cubes that were not coated with dacryodes edulis but were not exposed to a corrosive environment. The reinforced concrete cubes were subjected to tensile and pull out bond strength in order to access the effectiveness of the resin on the corrosion prevention, by enhancing the tensile and pull out bond strength of the reinforcement in the experimental cubes. Results obtained indicated that the failure bond strength, pull out bond strength and maximum slip of the resin coated reinforced cubes were higher by (19\%), (84\%) and (112\%). respectively than those obtained from the controlled tests. Similar results were obtained for the maximum slip (the resin coated and non-corroded steel members) had higher values of maximum slip compared to the cubes that had corroded steel reinforcements. For the corroded beam members, the failure bond strength, pull out bond strength and maximum slip of the resin coated reinforcements were lower by (22\%), (32\%) and (32\%). respectively than those obtained from the controlled tests. The resin (mdacryodes edulis) inhibit corrosion of the reinforcement, hence enhanced strength to the reinforcement.
\end{abstract}

Keywords: Bond strength, Concrete (reinforced), Ccorrosion, Resins Slip, Tensile strength

\section{INTRODUCTION}

Corrosion of steel reinforcement is generally the most important factor that shortens the service life of reinforced concrete structures that are subjected to corrosive environments.

A major cause of steel reinforcement corrosion is the presence of chlorides from chloride contaminated aggregates and admixtures containing chlorides which are used during construction, or from penetration of chloride ions from sea water or ingress of de-icing salt. Shetty, et al. [1] established that corrosion of reinforcing steel is widely accepted as the primary cause of premature deterioration in reinforced concrete structures.

Fu and Chung [2] also observed that corrosion is one of the main causes of the limited durability of reinforced concrete. Ting and Nowak[3] established that the carrying capacity of a reinforced concrete beam lies purely on the strength of steel reinforcement. The strength reduction of the reinforced concrete, as a result of corrosion is a linear function of the loss of material of the steel reinforcement.

Huang and Yang [4] carried out experiments on reinforced concrete beams of predetermined cracks in order to study the effect of reinforcing steel area loss on the flexural actions of reinforced concrete beams. They discovered that the load carrying capacity of reinforced concrete beams decreased as the corrosion of the reinforcing steel increased. The loss of reinforcing load carrying capacity was calculated to ascertain the percentage reduction of the steel bar diameter resulting from corrosion. The experimental

\footnotetext{
* Corresponding author, tel: +234-803-310-6918
} 
results showed that the load carrying capacity of such beams was reduced by $10 \%$.

Yoon et al [5] also investigated concrete beam specimens reinforced with a single standard Grade 60 reinforcing steel bar. An epoxy coating was applied on the reinforcing steel bar to reduce the corrosion potential and the effect of steel corrosion was subsequently examined. It was observed that the flexural loading capacity of the concrete beams decreased as the percentage weight loss of the reinforcing steel increased. This is an indication that the loss of the loading capacity might be primarily due to the loss of steel-concrete bond. The reduction of the remaining load carrying capacity of a beam corresponds with the steel-concrete bond failure as observed from the flexural load testing.

Cabrera [6] experimented on six corroded beams reinforced with top and bottom bars of two $10 \mathrm{~mm}$ and $12 \mathrm{~mm}$ plain top bars, with shear links of $8 \mathrm{~mm}$ at $40 \mathrm{~mm}$ spacing, as a web reinforcement along the shear span of $384 \mathrm{~mm}$. $2 \%$ chloride content was added to the concrete to accelerate the corrosion process. It was observed that the moment carrying capacity increased by $20 \%$. An approximately linear decrease occurred in the moment capacity as the percent of mass loss increased.

Rodriguez [7] also investigated the level of different corrosion degrees on concrete beams. The results showed that corrosion increases deflections and cracks widths at the service load, decreases strength at ultimate load and causes an increase in both the spacing and width of transverse cracking due to bond deterioration.

Pandian and Mathur [8] established the use of natural products as corrosion inhibitor for metals in corrosive media.

Auyeung et al [9] studied the bond behaviour of corroded reinforcement bars and discovered that when the mass loss of the reinforcement due to corrosion reaches approximately $2 \%$, concrete cracks along the bar. It was observed that a small amount of corrosion increases both the bond strength and bond stiffness, but the slip at failure decreases considerably. However, it was also observed that when the mass loss exceeds $2 \%$, the bond stiffness decreases considerably.

Rasheeduzzafar et al [10] conducted seven years site exposure tests and evaluated the performance of corrosion resting steels in chloride media. Evaluation of bare mild, steel, galvanized, epoxy-coated and stainless steel clad reinforcing steels embedded in concrete and exposed the following levels of chloride content $(0.6,1.2$, and $4.8 \%)$ was carried out. It was observed that bare mild steel bars suffer severe rust related damage in all the three chloride levels, whereas the galvanized steel resisted corrosion in high chloride levels, while epoxy-coated steel bars offered appreciable corrosion resistance only in low chloride levels.

Rasheeduzzafar et al [11] recommended the following concrete cover for structures serving in various environment of the Arabian Gulf:

(i) Building components which are permanently exposed to the salt-laden corrosive atmosphere -2 inches.

(ii) Building components which are protected against weather and the aggressive condition of exposure: 1.0 to 1.5 inches.

(iii) Concrete components exposed to sea water and footings as well as other main structural members cast against the ground: 3.0 inches.

Uomoto and Misra [12] used a different method to establish that the cause of structural deterioration resulting from the reinforcement corrosion is indirectly interrelated to the loss of strength of the bars resulting from cross-sectional area reduction, which are caused by factors such as crack development in concrete and bond could lead to greater reduction loss of strength of the structure.

The load carrying capacity of RC beams decreased as the corrosion product increased. The loss in reinforcing load carrying capacity was calculated to ascertain percentage reduction of the steel bar diameter resulting from corrosion. Experimental results showed that loading capacity was reduced by $10 \%$.

When steel reinforcements corrode, the life span, service life and intended purpose and its integrity and capacity of the structure are reduced Bond strength of reinforcement embedded in concrete are influenced by the geometry, concrete properties, the presence of surrounding bars and surface conditions, [13].

This study is aimed at determining effectiveness of resins/exudates of trees in corrosion prevention of reinforcement in reinforced concrete structures. Dacryodes edulis (native pear) is abundantly available in Nigeria. Foreign exchange will be saved by using the resin from daceryodes edulis as a corrosion inhibitor.

\section{MATERIALS AND METHODS}

\subsection{Materials}

\subsubsection{Aggregates}

The fine aggregate (washed sand deposit) was obtained from the Imo River,at Oyigbo Local Government Area of Rivers State in Southern Nigeria., while the coarse aggregate was crushed rock with a 
sizeof $12 \mathrm{~mm}$. Both aggregates met the requirements of [14].

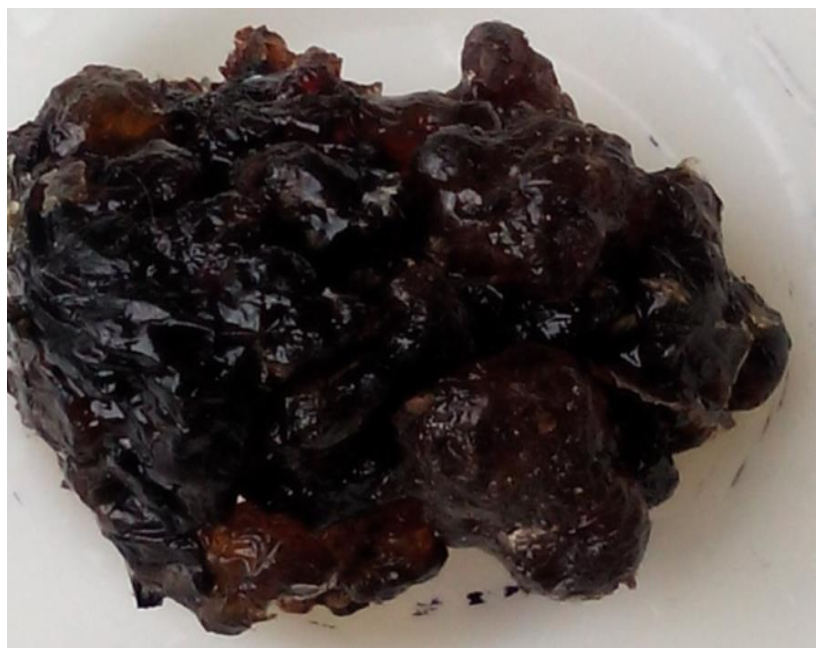

Fig. 1: Resin of the dacryodes edulis (solid form) after extraction from the bark of the tree.
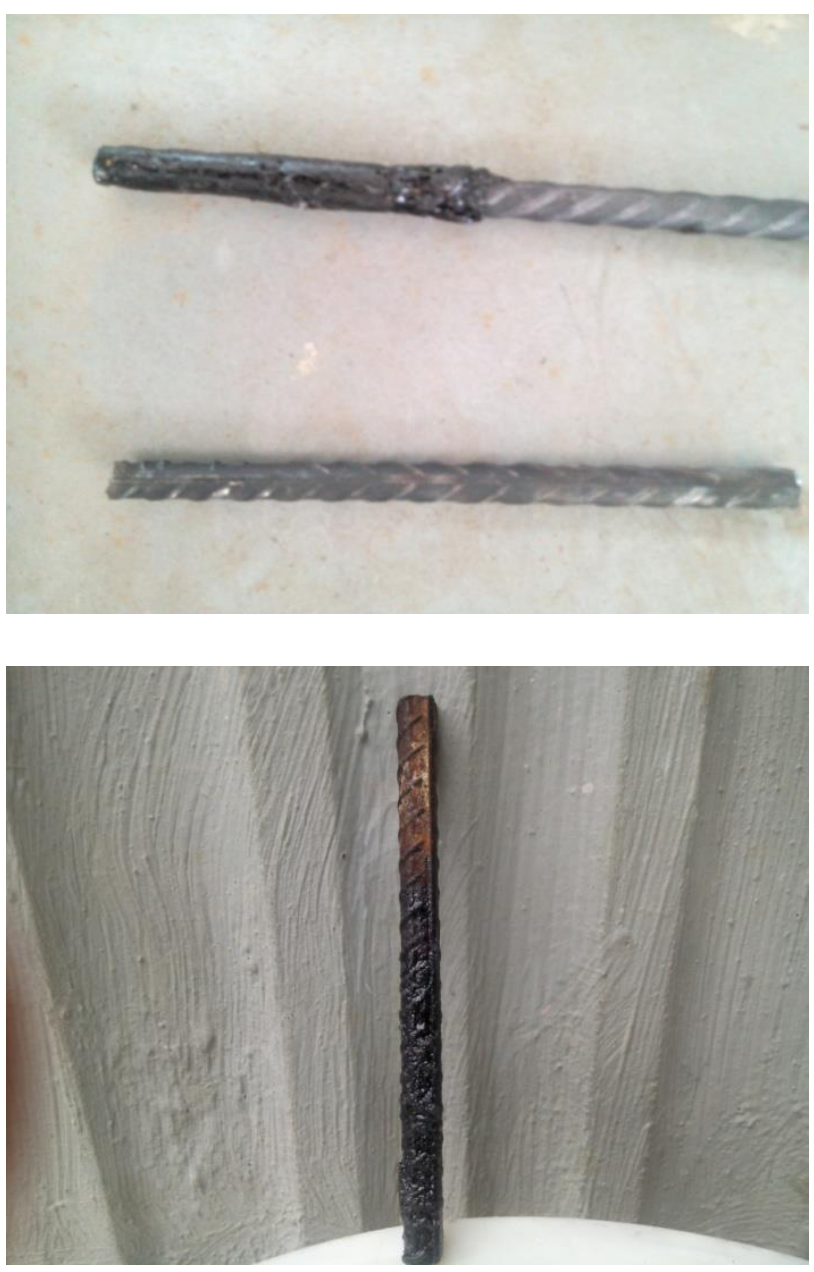

Figure 2: Coated and uncoated reinforcing bars

\subsubsection{Cement}

The cement usedwas Eagle Portland Cement, it was usedfor all concrete mixes in this investigation and it met the requirements of [15].

\subsubsection{Water}

The fresh water used was obtained from the tap at the Civil Engineering Department Laboratory, University of Uyo, Uyo. Akwa - Ibom State. The water samples were clean and free from impurities and it met the requirements of [16].

\subsubsection{Structural Steel Reinforcement}

The reinforcements was obtained from the Building Material Market in Port Harcourt. The steel met the requirements of [17].

\subsubsection{Corrosion Inhibitors (Resins / Exudates) \\ Dacryodes edulis (African Pear)}

The inhibitor was obtained from the bark of (Dacryodes edulis (African Peartree). It is a natural tree resin /exudate substance extract. The dacryodes edulis trees are abundantly found in Rivers State bushes and they are sourced from plantations and bushes of Odioku communities, Ahoada West Local Government areas, Rivers State. The local name in South Eastern Nigeria where this is abundantly found is UBE.

\subsection{Method}

\subsubsection{Extraction of the resin/exudates}

The bark of the dacryodes edulis tree was cut with a cutlas in several places at the trunk of the tree. The resins bled from the cut portions of the tree trunk and were collected 2 days. It hardened after two days. They were heated to $60^{\circ} \mathrm{C}$ in order attain a liquid state at the point of application. Fig. 2 shows the resin of the dacryodes edulis tree in a solid form

\subsubsection{Sample preparation for reinforcement steel with coated resin/exudate}

Specimen surfaces roughness was treated with sandpaper / wire brush and specimens were cleaned with distilled water, washed by acetone and properly dried, then polished and coated withdacryodes edulis (african pear), resin pastes with coating thicknesses of $150 \mu \mathrm{m}, 250 \mu \mathrm{m}$ and $300 \mu \mathrm{m}$ before corrosion test.Caliper gauge was used to ensure that uniform thickness was obtained. The test cubes and beams were cast using steel mould with a dimension of size $150 \mathrm{~mm}$ $\times 150 \mathrm{~mm} \times 150 \mathrm{~mm}$. Fresh concrete mix (1:2:4)of each batch was fully compacted with tamping rods, to remove trapped air, which can reduce the strength of the concrete and $12 \mathrm{~mm}$ reinforcements of coated and non-coated reinforcing steel were spaced at $150 \mathrm{~mm}$ with concrete cover of $25 \mathrm{~mm}$ had been embedded inside the slab and projection of $100 \mathrm{~mm}$ for half cell 
potential measurement was allowed for. Specimens were de-moulded after $24 \mathrm{hrs}$ and cured for 28 days. The specimens were cured at room temperature in the curing tanks. The cubes were then placed in another tank containing 5\% NaCLper one litre of water to simulate accelerated corrosion for a duration of 60 days when first were crack noticed, making a total of 88 days for the experiment, Fig. 2 shows the coated and uncoated steel reinforcing rods.

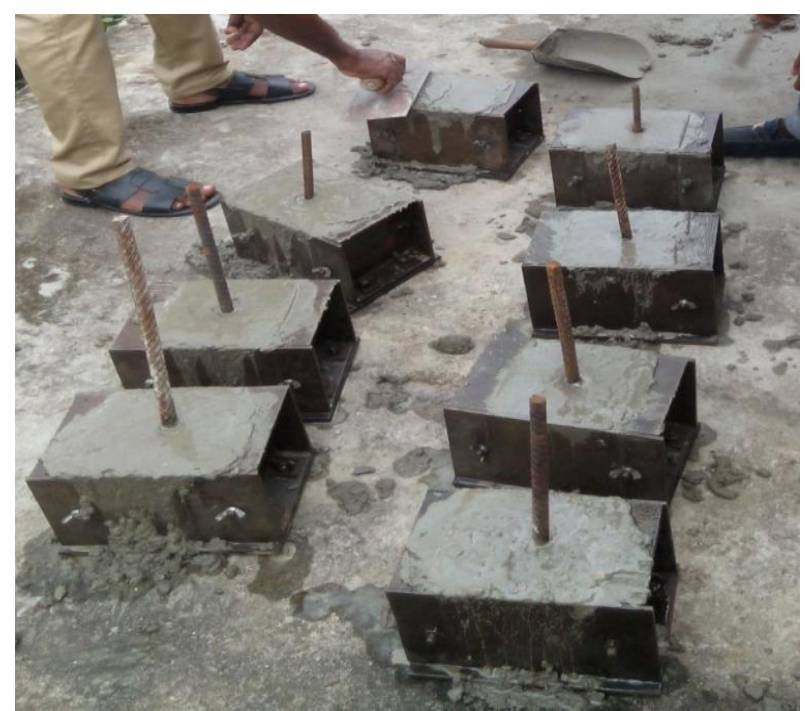

Figure 3: Placement of reinforcements into the cubes.

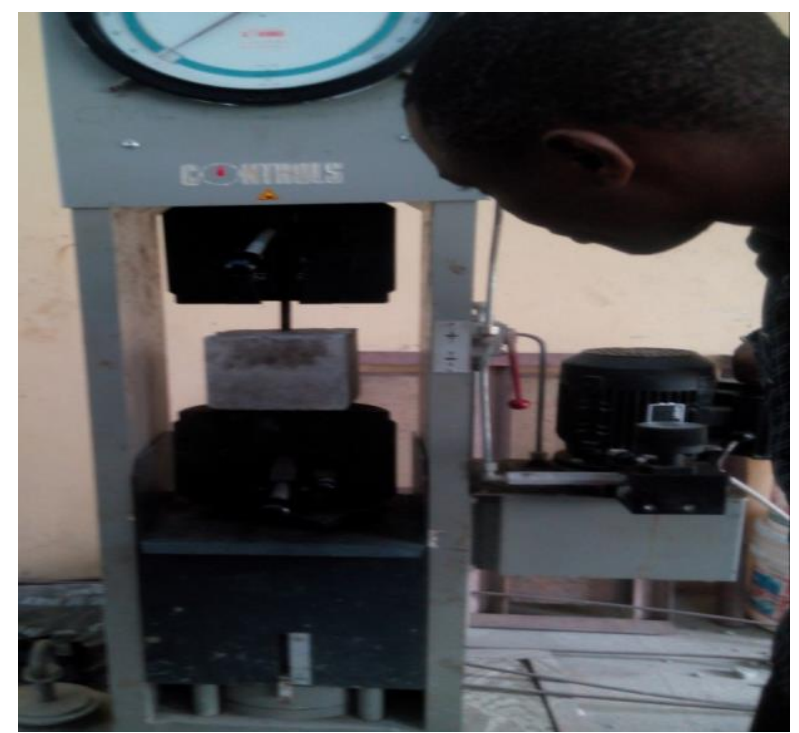

Fig. 4 Experimental set -up of the pull out test

\subsubsection{Casting of the Concrete Cubes}

27 concrete cubes were cast for the entire experiment. From table 1, cubes ( A to I) represent the 9 cubes for the non-corroded cubes (control experiment). Another set of 9 cubes were cast for immersion in the corrosive medium. A further set of 9 cubes were cast with reinforcement steel coated with 150, 250 and 350 thick pastes of dacryodes edulis. Specimen (A, B and C) , (D,
E AND f) and ( G., $\mathrm{H}$ and I) represent the samples for $150 \mu \mathrm{m}, 250 \mu \mathrm{m}$ and $350 \mu \mathrm{m}$ thick. Thereinforcement steels samples were coated with the dacryodes edulis and left to dry for 2 days. Fresh concrete of mix ratio 1:2:4 and water/cement ratio of 0.4 , was poured into a mould and the steel rods were dipped into the mould at the centre. Fig. 3 shows the placement of the reinforcement rods in the concrete cubes.

\subsubsection{Accelerated corrosion set-up and testing procedure}

In real and natural conditions the development of reinforcement corrosion is very slow and can take years to occur. To overcome the long delay based on this, previous, laboratory studies have indicated that acceleration of corrosion process can be achieved after a short test period. After curing of the reinforced concrete cubes specimens for 28 days, the cubes were placed in the corrosion tank for another 60 days to induce desired corrosion levels. Electrochemical corrosion technique was used to accelerate the corrosion of steel bars embedded in beams specimens. The reinforced concrete cubes were immersed in a corrosion tank containing 5\% NaClper one litre of water) for duration of 60 days, before examination of the specimens.

Abrosa [18] investigated the corrosion of steel in reinforcement in concrete. He studied the effect mild steel and 316L stainless steel in reinforced concrete by immersing them, in 1, 3 and $5 \%$ saline ( $\mathrm{NaCl}+$ Distilled water). Changes in the surface conditions of the various steels used were noticed due to corrosion from the saline solution that was used.

\subsubsection{Pull-out Bond Strength Test}

The pull-out bond strength tests on the concrete cubes were performed with the aid of on 54specimens on Universal Testing Machine of capacity $50 \mathrm{KN}$ in accordance with [19]. After curing for 28days,9controlled reinforced cubes(non-corroded) was kept in a control (non corrosive medium)condition to ascertain bond difference effects, 9reinforced cubes samples of non-coated and another 9 samples resin / exudates coated were then placed in a corrosive ponding tank for 60 days. After 60days, the samples coated with resins and subjected to corrosion were examined to determine the effect of corrosion on the bond strength and tensile strength on the steel used to reinforce concrete members. 


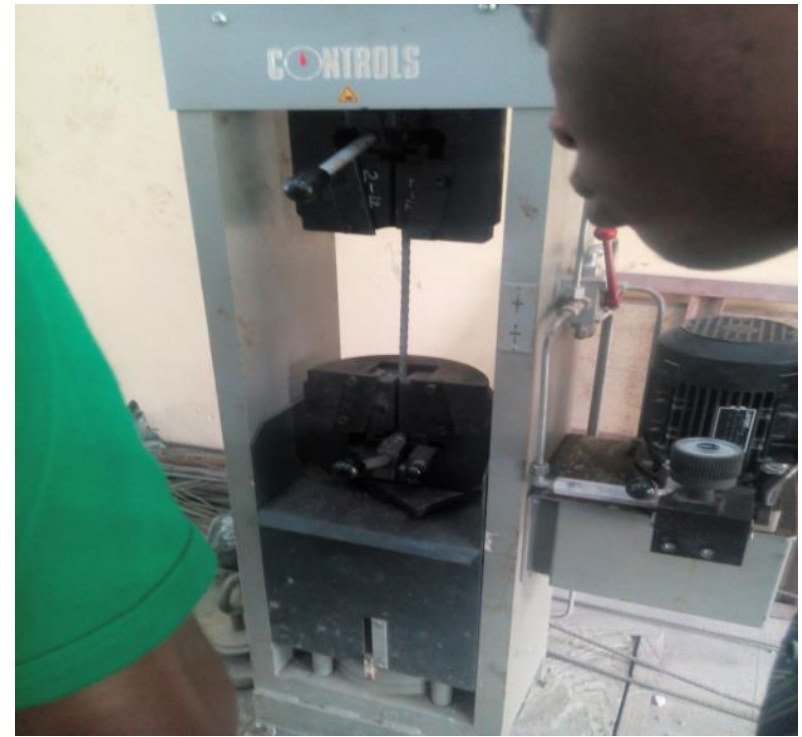

Fig. 5 Experimental set-up of the tensile test.

For the pull out bond strength, the dimensions used for the specimens was $150 \mathrm{~mm} \times 150 \mathrm{~mm} \times 150 \mathrm{~mm}$ with a single ribbed bar of $12 \mathrm{~mm}$ diameter embedded in the centre of the concrete cube. The bond length of the bar was $40 \mathrm{~mm}$ long.protruding from the top of the specimen and with the outer $75 \mathrm{~mm}$ of the reinforcing bar enclosed in a PVC tube to ensure that these sections remained un-bonded. The un-immersed portion of the steel rods was used to hold the rods for pulL out. The reinforcement bar was covered with tape for a distance of $75 \mathrm{~mm}$ from both ends of the cube so that the corrosion could take place within the $50 \mathrm{~mm}$ bonded length. The pull-out bond tests were conducted using an Instron Universal Testing Machine of 50KN capacity at a slow loading rate of $1 \mathrm{~mm} / \mathrm{min}$. the reinforced concrete cube specimens were cured in water for 28 days, and with $5 \% \mathrm{NaCl}$ per one litre of water for same 60 days and making a total of 88 days. Fig. 4 showes the experimental set-up for the pull out bond strength.

\subsubsection{Tensile Strength of Reinforcing Bars}

To ascertain the yield and tensile strength of tension bars, bar specimens of $12 \mathrm{~mm}$ diameter of noncorroded, corroded and resin coated were tested with tension in a Universal Testing Machine and were subjected to direct tension until failure; the yield or load at failure being recorded. An extensometer, of 50 mm gauge length, was used to measure the extension of the bars during the test and a data logger connected to a computer recorded the load and the corresponding extension of the bar as the test progressed. The complete load-elongation, hence stress-strain plots, were obtained. From the stress-strain plots, yield strength and tensile strength of the bars were determined. The experimental set-up for the tensile strength is shown in Fig. 5.

\section{RESULTS AND DISCUSSION}

\subsection{Physiochemical Analysis of the Resin (Dacryodes edulis- Nigerian Pear)}

Table 3 shows the physiochemical analysis of the resin obtained from the bark ofthe(dacryodes edulisNigerian Pea tree). The Chemical Analysis was performed at the PETRO-CHEMICAL Laboratory of the Rivers State University. The components probably responsible for the corrosion inhibition properties are: calcium and moisture. This is as a result of the formation of Calcium Hydroxide $\mathrm{Ca}(\mathrm{OH}) 3$, by the calcium (60\%) and water (28.60\%) in the dacryodes edulis. Calcium Hydroxide is a white powder or colourless crystal chemical compound that is formed by reacting lime and water. Calcium hydroxide can be used as a protective coating substance to prevent surface corrosion on some metals [20].

Table 3: Physiochemical Analysis of African Pear (Dacryodes Edulis).

\begin{tabular}{cllll}
\hline S/No. & \multicolumn{1}{c}{ Parameter } & Test Method & Result & \multicolumn{1}{c}{ Standard } \\
\hline 1 & Potassium (\%) & APHA 3111 & 0.008 & 0.10 \\
2 & Magnesium (\%) & APHA 3111 & 0.04 & 0.10 \\
3 & Calcium (\%) & APHA 3111 & 60.14 & 70.0 \\
4 & Phosphate (\%) & APHA 3111 & 0.017 & 0.50 \\
5 & Manganese (\%) & APHA 3111 & 0.05 & 0.50 \\
6 & Sulphate (\%) & APHA 3111 & 0.030 & 1.00 \\
7 & Aluminium (\%) & APHA 3111 & 0.030 & 1.00 \\
8 & Acidity number $(\mathrm{KOH} / \mathrm{g})$ & APHA 3111 & 0.019 & 0.05 \\
9 & Lead (\%) & APHA 3111 & 0.015 & 0.05 \\
10 & Copper (\%) & APHA 3111 & 0.055 & 0.50 \\
11 & Arsenic (\%) & APHA 3111 & 0.017 & 0.10 \\
12 & Ash content (\%) & APHA 3111 & 1.19 & 2.0 max \\
13 & Moisture content $(\%)$ & APHA 3111 & 28.60 & 30 max \\
14 & Density (kg/m $\left.{ }^{3}\right)$ & APHA 3111 & 2.35 & $1.0-2.5$ \\
15 & Iron & APHA 3111 & 0.206 & 0.5 \\
\hline
\end{tabular}




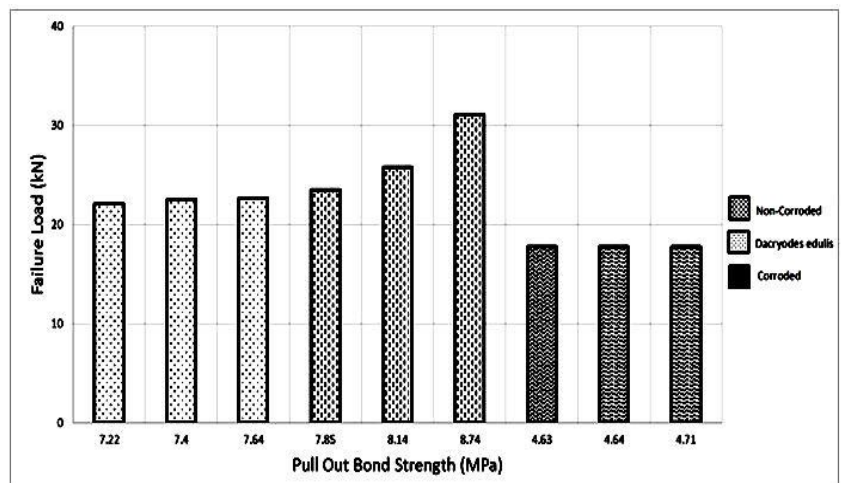

Figure 8: Bar chart of Failure of load versus pull-out bond strength$$
10
$$

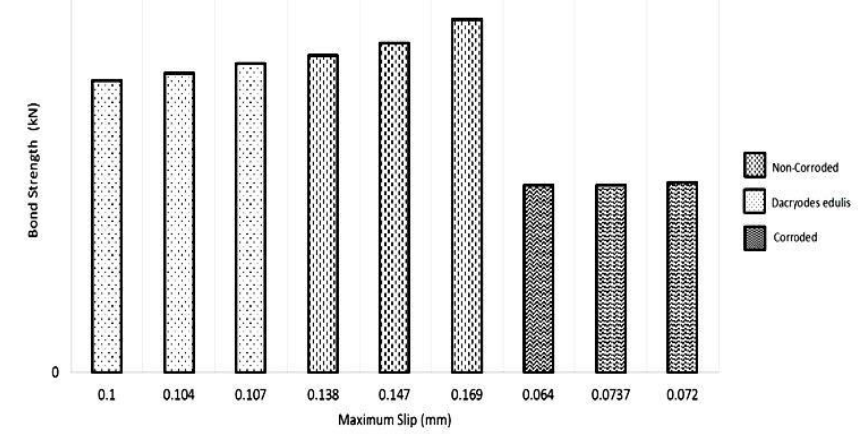

Figure 7: Bond strength versus maximum slip

\subsection{General Discussion}

Table 1 shows the entire results of the failure bond load, pull out bond strength, maximum slip for the control, corroded and resin/exudates (Nigerian Pear dacryodes edulis) coated steel reinforcement beams, while the results of the average values of the failure bond load, pull out bond strength and maximum slip of non-corroded, corroded and resin/exudates coated steel coated beams are presented in Table 2 .

Figure 6 is the bar chat of the failure bond load versus the pull out bond strength while, figure 7 is the bar chat of Bond Strength versus the maximum slip. The non-corroded reinforced concrete cubes served as the control. The percentage increase or decrease of the parameters mentioned above were based on the control values.

All the percentage increase or decrease was calculated from Table 2. The average values of Samples A, B and C for the corroded was the reference. Average values of A, B and C were calculated for all the parameters. The average values of the corroded were subtracted from the non-corroded and dacryodes edulis coated. The resultant was divided by the average value of the corroded.

\subsection{Pull Out Bond Strength Test/Maximum Slip}

From tables 2 and figure 6 , the pull out bond strength is not appreciably affected by the thickness of the resin of the (dacryodes edulis) tree. When compared to the non-corroded reinforced concrete cubes, the pull out bond strength decreased by $32 \%$, while the maximum slip decreased by $32 \%$. There was a $84 \%$ increase in the pull out bond strength and an increase of $112 \%$ in the maximum slip for the dacryodes edulis coated reinforced concrete cubes, the pull out bond load increases and the bond strength increases as the maximum slip increases. These results are similar to the works of [21] who observed that deflection increased as corrosion propagated. Han-Seung Lee et al (2002) also evaluated the degree of corrosion reinforcement as a function of bond properties between concrete and reinforcement. They observed that maximum bond strength and bond rigidity decreased in proportion with increase in corrosion percentage..

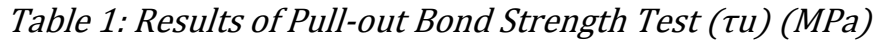

\begin{tabular}{|c|c|c|c|c|c|c|c|c|c|c|}
\hline 2 & \multicolumn{7}{|c|}{ Corroded } & & & \\
\hline CCk 2-1 & Failure Bond load (KN) & 17.34 & 18.09 & 17.86 & 18.32 & 17.57 & 17.50 & 18.09 & 17.57 & 17.55 \\
\hline CCk 2-2 & Bond strength (MPa) & 4.25 & 4.90 & 4.75 & 5.27 & 4.71 & 4.46 & 4.87 & 4.56 & 4.48 \\
\hline CCk 2-3 & Max. slip (mm) & 0.054 & 0.080 & 0.073 & 0.085 & 0.072 & 0.072 & 0.078 & 0.070 & 0.070 \\
\hline \multirow[t]{3}{*}{ CCk 2-5 } & Bar diameter $(\mathrm{mm})$ & 12 & 12 & 12 & 12 & 12 & 12 & 12 & 12 & 12 \\
\hline & \multicolumn{10}{|c|}{ Coated specimens } \\
\hline & & \multicolumn{3}{|c|}{$\begin{array}{l}(150 \mu \mathrm{m}) \text { coated }(\mathrm{A}, \mathrm{B}, \\
\mathrm{C})\end{array}$} & \multicolumn{3}{|c|}{$\begin{array}{l}(250 \mu \mathrm{m}) \text { coated }(\mathrm{D}, \mathrm{E}, \\
\mathrm{F})\end{array}$} & \multicolumn{3}{|c|}{$(350 \mu \mathrm{m})$ coated $(\mathrm{G}, \mathrm{H}, \mathrm{I})$} \\
\hline 3 & \multicolumn{10}{|c|}{ Dacryodes edulis ( steel bar coated specimen) } \\
\hline CCk 3-1 & Failure load (KN) & 22.97 & 24.25 & 23.15 & 25.60 & 24.98 & 26.70 & 32.50 & 30.78 & 29.99 \\
\hline CCk 3-2 & Bond strength (MPa) & 7.73 & 7.95 & 7.88 & 8.12 & 8.02 & 8.28 & 8.87 & 8.70 & 8.66 \\
\hline CCk 3-3 & Max. slip (mm) & 0.133 & 0.145 & 0.137 & 0.149 & 0.145 & 0.149 & 0.175 & 0.172 & 0.1615 \\
\hline CCk 3-4 & Bar diameter $(\mathrm{mm})$ & 12 & 12 & 12 & 12 & 12 & 12 & 12 & 12 & 12 \\
\hline
\end{tabular}


Effectiveness of Resins/Exudates of Trees in Corrosion Prevention of Reinforcement in... A. W. Otunyo \& C. Kennedy

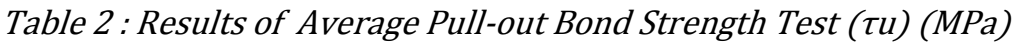

Control, Corroded and Resin Steel bar Coated

\begin{tabular}{|c|c|c|c|c|c|}
\hline S/N0 & & $\mathrm{A}$ & $\mathrm{B}$ & \multicolumn{2}{|l|}{$\mathrm{C}$} \\
\hline $\begin{array}{l}\text { Concrete } \\
\text { Cube }\end{array}$ & \multicolumn{5}{|c|}{ Non-corroded Control Cube } \\
\hline CCk1-1 & $\begin{array}{l}\text { Failure Bond Loads } \\
(\mathrm{kN})\end{array}$ & 22.09 & 22.46 & \multicolumn{2}{|c|}{22.66} \\
\hline CCk1-2 & Bond strength (MPa) & 7.22 & 7.40 & \multicolumn{2}{|c|}{7.64} \\
\hline CCk1-3 & Max. slip (mm) & 0.100 & 0.104 & \multicolumn{2}{|c|}{0.107} \\
\hline CCk1-4 & Bar diameter $(\mathrm{mm})$ & 12 & 12 & \multicolumn{2}{|c|}{12} \\
\hline 2 & \multicolumn{3}{|c|}{ Corroded } & & \\
\hline CCk 2-1 & Failure Bond load (KN) & 17.76 & 17.77 & & 17.74 \\
\hline CCk 2-2 & Bond strength (MPa) & 4.63 & 4.71 & & 4.64 \\
\hline CCk 2-3 & Max. slip (mm) & 0.069 & 0.0 .72 & & 0.073 \\
\hline \multirow[t]{3}{*}{ CCk 2-4 } & Bar diameter (mm) & 12 & 12 & & 12 \\
\hline & \multicolumn{5}{|c|}{ Coated specimens } \\
\hline & & $\begin{array}{l}150 \mu \mathrm{m}) \text { coated }(\mathrm{A}, \mathrm{B}, \\
\mathrm{C})\end{array}$ & $\begin{array}{l}(250 \mu \mathrm{m}) \text { coated }(\mathrm{D}, \mathrm{E}, \\
\mathrm{F})\end{array}$ & \multicolumn{2}{|c|}{$\begin{array}{l}(350 \mu \mathrm{m}) \text { coated }(\mathrm{G}, \mathrm{H}, \\
\mathrm{I})\end{array}$} \\
\hline 3 & \multicolumn{5}{|c|}{ Dacryodes edulis ( steel bar coated specimen) } \\
\hline CCk 3-1 & Failure load (KN) & 23.46 & 25.76 & 31.09 & \\
\hline CCk 3-2 & Bond strength (MPa) & 7.85 & 8.14 & 8.74 & \\
\hline CCk 3-3 & Max. slip (mm) & 0.138 & 0.147 & 0.169 & \\
\hline CCk 3-4 & Bar diameter $(\mathrm{mm})$ & 12 & 12 & 12 & \\
\hline
\end{tabular}

The results of the Pull Out Bond strength shows similarities with those carried out by [22], who reported a $9 \%$ loss of bond strength due to $4 \%$ loss of weight from corrosion accompanied by transverse cracks, and a $17.5 \%$ weight loss with no transverse cracks before yielding of the bar resulted in $92 \%$ loss of bond between the steel and the surrounding concrete

\subsection{Tensile Strength of Reinforcing Rods.}

The load at failure for the corroded reinforced cubes deceased by $22 \%$. When compared to the corroded reinforced cubes, there was a 19\% increase in the load at failure for the dacryodes edulis coated reinforced bars. This result is similar to those obtained by [23], which observed that the tensile strength of noncorroded steel reinforced concrete beam is greater than that of corroded steel.

\section{CONCLUSION}

The following conclusions were drawn from the results and discussion.

i. Bond stresses experienced in inhibitor coated reinforcements and reinforcements not coated but also not subjected to a corrosive environment are higher than values obtained with controlled specimens. ii. Tensile strength experienced in inhibitor coated reinforcements and reinforcements not coated but also not subjected to a corrosive environment are higher than values obtained with controlled specimens.

iii. Bond and tensile strength reduces linearly with increasing corrosion levels.

i.v. An increase in bond strength was experienced with increase in the thickness of resin

(dacryodes edulis-).

$\mathrm{V}$, The calcium and water in the native pear(dacryodes edulis) react to produce calcium hydroxide which is a substance capable of preventing corrosion to titanium and carbon steel metal surfaces.

\section{RECOMMENDATIONS}

The following are the recommendations for further study.

(a) the use of other corrosion accelerating media. different from $\mathrm{NaCl}$.

(b) the use of other plant extracts like pawpaw and magnifera indica (mango) tree extracts.

(c) the use of the other corrosion probability assessment techniques and methods. 
(d) the use of blend agents (slag, pozzolanas and fillers) that can reduce the permeability and rate of penetration of chloride ions) [24], and [25].

\section{ABBREVIATIONS}

ACI - American Concrete Institute.

ASTM - American Society for Testing of Materials

Results for failure loads, bond strength, Maximum slip and bar diameter for the Non-corroded control cubes respectively

CCk1-1

CCk1-2

CCk1-3

CCk1-4

Results for failure loads, bond strength, Maximum slip and bar diameter for the Corroded control cubesrespectively

CCk2-1

CCk2-2

CCk2-3

CCk2-4

Results for failure loads, bond strength, Maximum slip and bar diameter for the dacryodes edulis coated cubes respectively

CCk3-1

CCk3-2

CCk3-3

CCk3-4

A, B and C - Three sets of test cubes for $150 \mu \mathrm{m}$ coating thickness

D, E and F - Three sets of test cubes for $250 \mu \mathrm{m}$ coating thickness

$\mathrm{G}, \mathrm{H}$ and I - Three sets of test cubes for $350 \mu \mathrm{m}$ coating thickness

These values for the non-corroded and corroded simply refer to three sets of results.

KN- Kilo Newton

MPa - Mega Pascal

Nacl - Sodium Chloride

PVC - Poly Vinyl Chloride

\section{REFERENCES}

[1] Shetty, A. , Gogoi, I. and Venkataramana, K. Effect of loss of bond strength due to corrosion in reinforced concrete members. International Journal of Earth Sciences and Engineering. Vol. 4, (October), pp. 879-884., 2011.

[2] Fu, X. and Chung, D. D. L. Effect of Corrosion on the bond between concrete and steel rebar. Cement Concrete Research. Vol. 27, No.12, pp. 1811-1815, 1997
[3] Ting, S.C. and Nowak, A.S. Effect of Reinforcing Steel Area Loss on Flexural Behaviour of Reinforced Concrete Beams. American Concrete Institute- Structural Journal, pp. 309-314, 1991.

[4] Huang, R. and Yang, C. C. Condition Assessment of Reinforced Concrete Beams Relative to Reinforcement Corrosion.Cement and Concrete Composites, Vol. 19, pp. 131-137, 1997.

[5] Yoon, S., Wang, K. Weiss, W.J. and Shah, S.P. Interaction between Loading, corrosion and serviceability of reinforced concrete. American Concrete Institute- Materials Journal, Vol. 97, No.6, pp. 637-644, 2000.

[6] Cabrera, J. D. "Deterioration of Concrete Due to Reinforced Steel Corrosion. Cement and Concrete Composites. Vol. 18, No.1, pp. 47-59, 1996.

[7] Rodriguez, J., Ortega, L. M and Casal, J. Load Carrying Capacity of Concrete Structures with corroded reinforcement. Construction and Building Materials, Vol. 14, No. 4, pp. 239-247, 1997.

[8] Pandadian, B. R. and Mathur, G. S. Natural Products as Corrosion inhibitor for metals in corrosive media - a Review. Science Direct, Vol. 62, No.1, pp. 113-116, 2006.

[9] Auyeung, Y., Balogun, P. and Chung, L.. Bond Behaviour of corroded reinforcement bars. American Concrete Institute- Materials Journal, Vol. 97, No. 2, pp. 214-220, 2000.

[10] Rasheeduzzafar, Dakhil, F. H. and Bader, M. A. Performance of corrosion resisting steel in Chloride-Bearing Concrete. Concrete International, American Concrete Institute, Vol.89, No.5, pp. 439-448, 1992.

[11] Rasheeduzzafar, Dakhil, F. H. and Bader, M. A. Toward solving the concrete deterioration problem in the Arabian Gulf region. The Arabian Journal for Science and Engineering, Vol. 11, No. 9, pp, 129-146, 1986

[12] Uomoto, T., and Misra, S. "Behaviour of concrete beams and columns in marine environment when corrosion of reinforcing bars take place". ACI Special Publication SP-109-6, PP. 127-145. 1988.

[13] ACI. Bond and Development of Straight Reinforcing Bars in Tension. American Concrete Institute, Farmington Hills, MI, USA, 2003.

[14] BS. 882; Specification for aggregates from natural sources for concrete. British Standards Institute. London, United Kingdom, 1992.

[15] BS EN 196-6; - Methods of Testing Cement. Determination of fineness, British Standards Institute. London, United Kingdom, 2010.

[16] BS 3148 - Methods of test for water for making 
concrete. British Standards Institute. London, United Kingdom, 1980.

[17] BS 4449:2005+A3 - Steel for Reinforcement of Concrete. British Standards Institute. London, United Kingdom, 2010.

[18] Abosra, L. R. Corrosion of steel reinforcement in concrete. Ph.D. Thesis, University of Bradford, School of Engineering, Design and Technology, 2010.

[19] ASTM C1583/C1583M-13 - Standard Test Method for Tensile Strength of Concrete Surfacing and Bond Strength or Tensile Strength of Concrete/Repair by Direct Tension (Pull-Out method and Overlaying Materials, ASTM International, West Conshohocken, PA, 2013.

[20] https://www.corrosionpedia.com. What does Calcium Hydroxie mean. Accessed $3^{\text {rd }}$ October 2017.

[21] Balim, Y. and Reid, J. C. Reinforcement corrosion and the deflection of RC beams: An experimental critique of current test methods Cement and Concrete Composites, Vol. 25, No.6, pp. 625-632, 2003.

[22] Amlieh, L. and Mirza, S. Corrosion influence on bond between steel and concrete, ACI Structural Journal, Vol. 96, No.3 pp.415-423.

[23] http://eprints.uwe.c.uk/2218. The Effect of Steel Reinforcement Corrosion on Tensile strength, bond strength and flexural strength. Accessed on 24/11/2017.

[24] Thomas, M. "Chlorides thresholds in marine concrete, Cement and Concrete Research, Vol. 26, pp. 513-519, 1996.

[25] Vedalakshmi, R., Rajagopal, K. and Palaniswamy, N., Long-term corrosion performance of rebar embedded in blended cement concrete under macro cell corrosion condition, Construction and Building Materials, Vol. 22pp. 186-199, 2008. 